Pamiętnik Literacki 2015, 3, s. 63-71
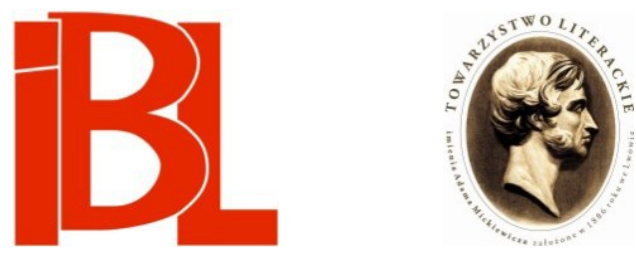

\title{
Kat, sędzia i ofiara w „Spowiedzi” Calka Perechodnika
}

Grzegorz Sierocki 


\title{
KAT, SĘDZIA I OFIARA W „SPOWIEDZI” CALKA PERECHODNIKA
}

\author{
O jedno tylko proszę: wykonajcie, ludzie, wiernie mój testa- \\ ment zemsty i wspomnijcie choć czasami świetlana postać mej \\ żony Anki i anielski wygląd mej córeczki Athalie ${ }^{1}$.
}

\section{Świadectwo}

Spowiedź Calka Perechodnika należy do najbardziej wstrząsających świadectw Zagłady. Spisany przez żydowskiego policjanta z Otwocka pamiętnik obrazuje nie tylko rozmiary krzywd, jakie spotkały polskich Żydów, ale także osobisty dramat samego autora. Na krótki czas przed śmiercią Perechodnik prosi w niemal błagalnym tonie: zachowajcie pamięć o mojej rodzinie, wspomnijcie na niewinne postacie mojej żony i córki, uwierzcie w ich dobre serca. Zdaje on sobie sprawę, że ów testament będzie miał szansę wypełnić się wyłącznie w jednym przypadku. Sięga po pióro, by ocalić od zapomnienia wizerunki bliskich i zaświadczyć o historycznej prawdzie. Oczywiście wątpi, czy jego „list” wysłany z centrum żydowskiego piekła dotrze do postronnego czytelnika, ale pisze. Pisze, bo musi. Musi, ponieważ w przeszłości zawiódł zaufanie żony i córki. Tylko on potrafi opowiedzieć ich losy: krótkie i piękne życie oraz straszliwą i hańbiącą śmierć. Tylko on, Calek Perechodnik - kat, sędzia i ofiara, lecz przede wszystkim człowiek.

Powstawaniu Spowiedzi towarzyszyły ekstremalnie trudne warunki egzystencji. Dzięki znajomościom swojego ojca Perechodnik po wysiedleniu Otwocka przeniósł się do Warszawy. Tutaj ukrywał się w melinie na ulicy Pańskiej. Między 7 maja a 19 października 1943 stworzył dzieło wyjątkowe - zapis gehenny żydowskiego policjanta, który odprowadził do wagonu zmierzającego w stronę Treblinki dwie najukochańsze osoby na świecie: dwuletnią córkę Alusię i małżonkę Annę. Jak zauważyła Maria Janion: „To dzieło, pełne przekleństw i złorzeczeń, samo stało się swoistym "dziełem przeklętym""2. Dodajmy tu wypowiedź Jarosława Ławskiego: „Pierwsza lektura tekstu Perechodnika jest zawsze porażająca: czytelnik ma wrażenie hipnotycznej, obezwładniającej siły, "mrocznego urzeczenia», które każe mu

1 C. Perechodnik, Spowiedź. Wyd. 3. Oprac. D. Engel. Warszawa 2011, s. 318. Do wydania tego odsyłam dalej za pomocą skrótu S oraz liczb wskazujących numery stronic.

2 M. J a n i o n, Ironia Calka Perechodnika. W: Bohater, spisek, śmierć. Wykłady żydowskie. Warszawa 2009, s. 259. 
zaliczyć Spowiedź do najdonioślejszych świadectw Wyniszczenia"3. Spowiedź to również pokłosie zmagania się $z$ własną słabością, tęsknotą, traumą. Perechodnik wraca do najboleśniejszych wydarzeń swojego życia. Zapełnia puste kartki papieru kolejnymi refleksjami na temat Zagłady, gdy ta zbiera potworne żniwo tuż za murem niepewnej kryjówki. Każdy szelest, głos, pukanie do drzwi może oznaczać koniec - koniec cierpienia, ale też koniec narracji. Perechodnik nie lęka się wszakże śmierci, lecz przerwania pisania $\mathrm{w}$ połowie drogi. $\mathrm{W}$ ostatnim zdaniu przedśmiertnej spowiedzi wyzna: „Nie chodzi o to, żeby łódź ma przybiła do brzegu, ale chodzi o to, żebym dążył do celu mego" (S 318). Ów życiowy cel niewątpliwie udało się osiagnąć.

Okoliczności śmierci Perechodnika na zawsze pozostaną tajemnicą. Najprawdopodobniej zmarł on na tyfus lub zginął z rąk szabrowników pod koniec października 1944. Jak niewiele zabrakło, by autor przeżył wojnę i oszukał bieg historii. Kilka dni wcześniej pamiętnik znalazł się w posiadaniu Magistra - Władysława Błażewskiego. David Engel w komentarzu do ponownego wydania Spowiedzi $i^{4}$ szczegółowo przedstawia niemal heroiczną walkę przyjaciół pisarza, najpierw o przetrwanie tekstu, a następnie o jego publikację ${ }^{5}$. Gdyby nie dobra wola, zaangażowanie i wytrwałość wrażliwych na niedolę Perechodnika ludzi, nikt nigdy nie usłyszałby o pospolitym policjancie $z$ otwockiego getta. Nikt nie poznałby wewnętrznych dylematów człowieka o potrójnym statusie: kata, sędziego i ofiary. W dalszej części artykułu próbuję dociec, jak te trzy role ujawniają się w literackim zapisie Perechodnika oraz za kogo uważa się sam autor $\mathrm{w}$ związku $\mathrm{z}$ wydarzeniami, w których uczestniczył.

\section{Perechodnik jako kat}

W lutym 1941 wstapił Perechodnik w szeregi Ghetto-Polizei. Również w Otwocku, wzorem innych gett, działała „rodzima” służba porządkowa. Niemcy upatrywali w żydowskich funkcjonariuszach pomocników przy likwidowaniu stłamszonego narodu. Oficerowie policji udaremniali ucieczki $z$ obozów, zwalczali szmugiel, a przede wszystkim dozorowali akcje wysiedleńcze. Szczególnie to ostatnie zadanie przyniosło żydowskiej policji obiegową opinię zdrajców. Hannah Arendt w książce Eichmann $w$ Jerozolimie zdecydowanie potępi przechodzenie ofiar Zagłady na stronę okupanta. Wybitna myślicielka XX w. napisze: „Dla Żydów rola, jaką przywódcy żydowscy odegrali w unicestwieniu własnego narodu, stanowi niewątpliwie najczarniejszy rozdział całej tej ponurej historii”.6.

Do niemieckiego planu eksterminacji przyłączył się także Perechodnik. Autor Spowiedzi uległ widokom potencjalnych korzyści, które miał dawać status uprzy-

J. Ław ski, Narracja i wyniszczenie. O „Spowiedzi” Calka Perechodnika. „Teksty Drugie” 2005, nr 4, s. 174-175.

4 Pamiętnik C. Pe r e ch od nika opublikowano po raz pierwszy w r. 1993, pt. Czy ja jestem mordercą? Edycja ta, podobnie jak i kolejna (1995), rażąco różniła się od przekazu oryginalnego. Dopiero w r. 2004 wyszło wydanie wierne oryginałowi, zatytułowane Spowiedź, wznowione w 2011 roku. Zob. Janion, op. cit., s. 259-260.

5 D. Engel, posłowie. S 319-323.

6 H. Ar en dt, Eichmann w Jerozolimie. Rzecz o banalności zła. Przeł. A. Szo s tki ew i c z. Kraków 1987, s. 151. 
wilejowanego Żyda. Łudził się, że mundur gwarantuje przetrwanie i bezpieczeństwo. Wojna zapowiadała się na dłuższą, niż początkowo sądzono, więc należało pomyśleć o ochronie najbliższych. Niemcy potrzebowali kogoś, kto wykona za nich najcięższą pracę, ale tylko na okres istnienia zamkniętych obszarów mieszkaniowych. Później pozbywali się nawet więźniów funkcyjnych. Perechodnik dopiero po czasie zrozumiał perfidię niemieckiego planu. $Z$ wyraźną drwina wypowiada się na temat zachowania strażników i ich faktycznych zysków z kolaboracji:

Dano im pałki do ręki, toteż bili robotników, ile popadło, wszak dyscyplina musi być. Odbywali musztry z robotnikami przez długie godziny, jakby to było najważniejszą rzeczą w życiu Żyda. To nic, że robotnicy są zmęczeni po pracy lub też chcą wykorzystać wolną niedzielę dla siebie. „Równaj w prawo, równaj w lewo, baczność, spocznij, baczność, panie komendancie, melduję posłusznie, stan ludzi” - i tak trwała przez długie godziny zabawa w wojsko, ale w wojsko marionetek, które - jak pewnego dnia zjawi się żandarmeria razem ze swoim komendantem - położy się na ziemi i będzie po skończonej zabawie w komendanta i policję. [S 161]

Jednak w chwili deportacji Otwocka Perechodnik nie zważa na sytuację innych mieszkańców. We współpracy z niemieckimi napastnikami nadzoruje akcję wysiedlenia. Nie obchodzi go los starców, kobiet i dzieci odjeżdżających w nieznanym kierunku. Doniesienia o kolejnych transportach przyjmuje z ulgą, nie dotycza one bowiem jego rodziny. Wcielenie się w kata pozwala Perechodnikowi leczyć własne kompleksy. Zamiana ról odbywa się na zasadzie przejęcia obowiązków „prawdziwych" nazistowskich oprawców. Odszczepieńcy tylko pozornie zajmowali wyższą pozycję w hierarchii getta. W rzeczywistości odraczali datę swojego upokorzenia. Żaden Żyd nie mógł liczyć na łaskę totalitarnego mechanizmu, pomimo iż spełniał żądania przełożonych. Stawał się jedynie narzędziem, instrumentem podporządkowanym obcemu pożytkowi. Prędzej czy później ginął wraz z pozostałymi skazanymi ${ }^{7}$.

Perechodnik pojął ten potworny bilans żydowskiego położenia dopiero w momencie indywidualnej klęski. $Z$ trudem udaje mu się odtworzyć przebieg zdarzeń feralnego dnia wywózki.

Środa - 19 sierpnia 1942 roku, dzień zagłady nadszedł. Jakżebym chciał wiernie i dokładnie opisać ten dzień, opisać tak plastycznie, żeby każdy był w stanie uzmysłowić sobie, jaką gehennę przeżyli ludzie w ten przeklęty dzień, gdy nagle przekonali się, że się dali oszukać. [S 60]

Wtedy to, na długo przed biologiczną śmiercią, dokonuje się prawdziwy „dzień zagłady" autora Spowiedzi. Perechodnik staje się katem własnej rodziny. Najpierw ukrywa bliskich w piwnicy, potem namawia ich do wyjścia z kryjówki, gdyż ufa słowom komendanta obozu: „Sprowadź ją pan na plac z dzieckiem, zostanie zwolniona, na moją odpowiedzialność" - Kronenberg obieca Perechodnikowi, a ten naiwnie mu uwierzy (S 62). Wyprowadzi żonę wraz z córką na plac, gdzie nie będzie już dla nich ratunku. Możemy tu mówić o tragicznej pomyłce Perechodnika, ponieważ liczne kobiety ukrywające się w murach miasta przeżyły wysiedlenie. Fakt ten nie pozwala mężczyźnie zapomnieć, iż ponosi winę za śmierć niewinnych i drogich jego sercu istot. $\mathrm{W}$ oczekiwaniu na bezwzględny wyrok nazistów po raz pierwszy uznaje siebie za kata, co potem skomentuje w swoich zapiskach: „Mało, żem ją

$7 \quad$ Zob. J a nio n, op. cit., s. 272-276. 
stracił, ale musiała mi zostać jeszcze świadomość, że ja byłem jej katem, który ją zaprowadził na śmierć” (S 62). Na śmierć okropną i nieludzką, bez prawa do pogrzebu i mogiły ${ }^{8}$. Widmo śmierci w krematorium niejednokrotnie popycha Żydów do straszliwych postanowień. Sam Perechodnik w popłochu przetrząsa miasto, by pozyskać truciznę dla żony i córki. Ostatecznie nie zażywają one tabletek, ale mężczyzna wciąż pamięta, że chciał je otruć. On wycofuje się z przerażającej decyzji, podczas gdy inny autor żydowskiego pochodzenia, Stanisław Wygodzki, podaje truciznę swoim bliskim i sam ją zażywa. Żona i córka zginęły, ale Wygodzki ocalał. Rozrachunek $\mathrm{z}$ mroczna przeszłością to jeden $\mathrm{z}$ głównych motywów powojennego pisarstwa autora Pamiętnika miłości ${ }^{9}$.

Perechodnik wraca na plac i musi dokonać wyboru. Albo opuści Alusię i Ankę, albo pójdzie $z$ nimi na pewną śmierć. Albo okaże się zdrajcą, albo pozostanie solidarny $z$ bliskimi. Albo potulnie odejdzie z miejsca kaźni, albo zaprotestuje przeciwko bestialstwu nazistów i wsiądzie do „wagonu śmierci”. Sytuację bliźniaczą wobec tej, w której znalazł się Perechodnik, przedstawia Ida Fink w opowiadaniu Wariat. Tytułowy bohater odwraca wzrok od dzieci proszacych go o pomoc. W kilka lat po wojnie relacjonuje swoją „chorobę” bezradnemu lekarzowi:

Panie doktorze! Na pierwszym aucie stały moje dzieci, moje trzy... Widziałem, że starsza wie, ale że tamte płaczą ze zwykłego strachu. Nagle przestały płakać i najmłodsza - trzy latka! - zawołała: Tato, tato, chodź do nas!

W i d z i a ły. One jedne odkryły mnie w tym kącie. Tylko ich oczy. Panie doktorze! - no i co? Ojciec... wyszedłem, pobiegłem do nich i razem... tak?

A ja przyłożyłem palec do ust, zagryzłem go ze strachu i trząsłem głową, że nie wolno wołać, żeby były cicho - sza! ${ }^{10}$

Również Perechodnik przyznaje, że nie miał odwagi oddać opaski policjanta i w tym przypomina postać ojca $z$ opowiadania Fink. Ale ten drugi od początku bał się wykrycia przez szmalcowników. Był jednostką słabą, mało odporną psychicznie, panicznie lękająca się nawet wyjścia $z$ domu. Przecież człowiek ten zamiatał ulice getta, gdzie miotła służyła za towarzyszkę żydowskiej niedoli. A Perechodnik? Z dumą nosił mundur funkcjonariusza Ghetto-Polizei w Otwocku. Czuł się silny, ważny i potrzebny nazistowskim oprawcom. Wydawało mu się, że jest zbyt cenny dla zbrodniczego systemu, by ktokolwiek mógł zagrozić jego bliskim. Jak okrutna okazała się weryfikacja poglądów Perechodnika w wojennej rzeczywistości. Nikt z władz getta nie ujął się za jego żoną i córką, a zaufanie do przełożonych sprowadziło katastrofę na tę rodzinę. Funkcja policjanta naznaczyła Perechodnika piętnem zdrajcy i zbrodniarza, który w milczeniu przyglądał się pociągowi podążającemu w kierunku Treblinki.

Zdaje się nam, że stoimy na miejscu, ale nie, nogi wbrew naszej woli uniosły nas na drugi koniec placu. Szatan niemiecki odsłania swe prawdziwe oblicze, już nie ma po co odgrywać komedii, 199 osób

8 O wpływie śmierci na godność człowieka pisze H.-G. G a d a m e r (Doświadczenie śmierci. Przeł. A. Żychliński. „Odra” 2007, nr 5). Według filozofa „doświadczenie śmierci zajmuje w historii ludzkości miejsce zupełnie centralne. Wolno człowiekowi może nawet powiedzieć: rozpoczyna jego stawanie się człowiekiem” (s. 68).

9 Zob. M. Szabłk ow s ka - Za r e m b a, „Tragarz pamięci”. Rzecz o Stanisławie Wygodzkim. W zb.: Ślady obecności. Red. S. Bu ryła, A. Molis a k. Kraków 2010.

10 I. Fin k, Wariat. W: Wiosna 1941. Warszawa 2009, s. 61. 
mogą Niemcy sami pofatygować się i załadować do wagonów. Odchodzą w ciemną noc bez pożegnania. $Z$ daleka widzimy tylko tuman i sylwetki, których już nie odróżniamy. Wszystko przepadło. [S 76]

Perechodnik jawi się jako kat w dwóch porządkach opowiadania o Zagładzie. W wymiarze ogólnym da się go określić mianem kata żydowskich rodzin, ponieważ należy do żydowskiej policji - organu pomagającego nazistom. W wymiarze indywidualnym jest katem własnej żony i córki, ponieważ przygląda się ich odjazdowi do obozu. Przy czym dla samego Perechodnika kluczowa wydaje się pespektywa osobista. To ona skłania autora do uznania winy. Ona wywołuje w nim wyrzuty sumienia. W końcu to ona popchnie go do opisania historii ,jednego $z$ wielu, jednego z milionów nieszczęśliwych ludzi, którzy się urodzili, wbrew swej woli i na swe nieszczęście, urodzili się, niestety, Żydami!” (S 9).

\section{Perechodnik jako sędzia}

Dzieło Perechodnika jest nie tylko literackim rachunkiem sumienia, ale też wnikliwym aktem oskarżycielskim. Twórca Spowiedzi przeprowadza żywiołowy atak na różne warstwy społeczeństwa żydowskiego. Właśnie dlatego odczytanie jego świadectwa budziło tyle kontrowersji wśród szerszej publiczności. Żydowski autor po raz pierwszy tak surowo i w formie tak jednoznacznie krytycznej ocenia nie tylko własny naród, lecz także samego siebie jako członka prześladowanej grupy. Perechodnik w żaden sposób nie wyklucza się z żydowskiej wspólnoty. Popełnił te same błędy, słuchał tych samych obietnic, wierzył w te same niemieckie zapewnienia. Już na wstępie narracji podkreśla, iż niczym nie odbiega od ludzi, o których przyjdzie mu mówić:

Moje życie jest typowe, a to dlatego, że nie mogę się poszczycić ani wybitniejszym rozumem, ani też przypadkowym szczęściem, że mnie się udało lepiej niż innym.

O nie! Wszystkie głupstwa, wszystkie błędy, które Żydzi popełnili, popełniłem również. Wszystkie nieszczęścia, wszystkie tragedie, które ich dotknęły, dotknęły mnie również w tej samej mierze. [S 9]

Perechodnik podda się „publicznemu” biczowaniu, w zamian za co nabywa moralne prawo do osądzania innych. Jest zarówno oskarżającym, jak i oskarżonym, sędzią, ale też podejrzanym. Idea sądu to ważny motyw żydowskiej literatury, $\mathrm{w}$ Spowiedzi przebiega on dwutorowo.

Już wcześniej wspomniałem, że Perechodnik spogląda krytycznie przede wszystkim na własne postępowanie. Do ostatnich swych dni przeklina moment, w którym samotnie wrócił do wysiedlonego Otwocka, zamiast bronić życia najbliższych. Powinien wszczać bunt, zabrać głos, a przynajmniej towarzyszyć ukochanym w drodze na śmierć. Nie zrobił tego, więc w pewnej mierze ponosi odpowiedzialność za zbrodnię. Tutaj kwestia winy prezentuje się dość typowo, ale Perechodnik idzie o krok dalej. Zwraca uwagę na problem dziedziczenia nieusuwalnej skazy. „Żydowskość" przechodzi z ojca na syna, z matki na córkę. Oczywiście, bohater żałuje swojego postępowania, lecz w równym stopniu żałuje tego, że urodził się Żydem. Przeniósł „żydowskość” na osobę dziecka, pozbawiając je normalnych warunków rozwoju. W jakimś sensie zabił je jeszcze przed narodzeniem. Gdyby nie mała, bezbronna istota - być może, przeżyłaby jego żona. Do tak drastycznych wniosków dochodzi zrozpaczony autor pamiętnika. Wikła się w gąszczu pytań bez odpowiedzi, gdzie pewna jest tylko nienawiść do własnej tożsamości: 
Córko, córko, dziś akurat kończysz dwa lata, akurat dziś, ach, gdybym wiedział, może bym Cię udusił własnymi rękami, dwa lata temu, toć pośrednio przez Ciebie Anka ginie. A może to Ty giniesz wskutek głupoty Twoich rodziców? Kto jest w ogóle w stanie zrozumieć, co jest przyczyną, a co jest skutkiem? [S 65]

W oskarżeniu imiennym widać zalążki oskarżenia zbiorowego. Perechodnik obnaża wady całego narodu. Nie chodzi tu tylko o przynależność do żydowskiej policji. Zresztą temu organowi władzy poświęca się w Spowiedzi zadziwiająco mało miejsca, jeśli wziąć pod uwagę demaskatorskie intencje autora. Zdumiewa fakt, że Perechodnik w analizie zachowań policjantów bardziej skupia się na getcie warszawskim niż na rodzinnym Otwocku, który znał od podszewki. Musiał wiedzieć o makabrycznych zajściach w getcie, doskonale orientował się w tajnikach pracy żydowskiego funkcjonariusza publicznego. Na pewno nieraz uczestniczył w rabunku mienia, pobiciach czy wyłudzeniach. Otwocka policja w niczym nie prezentowała się lepiej niż jej warszawski odpowiednik. A mimo to narrator Spowiedzi zdawkowo charakteryzuje lokalne środowisko policjantów. Zgadzam się z Ławskim, że to celowe uchybienie ujawnia „etyczną niejednoznaczność autora i dzieła"11. Oskarżenie Perechodnika jest oskarżeniem wybiórczym. Dotyczy trzech podmiotów Zagłady - nazistów, Polaków i Żydów, ale zarzuty nie rozkładają się równomiernie. Świadomość zdrady współbraci zbyt boli, stąd „żydowski kat” nie mówi o niej otwarcie i szczerze.

O wiele częściej Perechodnik wyraża swoją nienawiść do Żydów jako rytualnej wspólnoty uformowanej wokół jednej religii, mentalności, zwyczajów, tradycji. Tego typu agresja cechuje ludzi, którzy od dłuższego czasu zmagają się ze skutkami nazistowskiej opresji. „Znajdujący się w takim położeniu człowiek może o sobie myśleć w kategoriach, w jakich myślą wrogowie danej grupy, może przyjmować ich język, odnosić wypracowane przez nich symbole (najczęściej złowrogie) do siebie"12. Przywołajmy jeden z licznych fragmentów Spowiedzi, w których dochodzi do zanegowania żydowskiej tożsamości:

O czym myślisz, maso żydowska?

Jesteś bierna, zrezygnowana, milcząca. Nie wiedząc nawet, powtarzasz za wieszczem: „Zginać naród może $z$ własnej tylko winy, gdy nim ogarnie rozpacz głucha i senna i to zwątpienie, co mu nakaże, że w grobie spoczynek jest miękki”.

O wszystkim myślicie, tylko nie o tym, żeście potomkami Judy Makabeusza. Gdzie jest ten duch Wasz, który by gromkim głosem krzykną: „tomus nafszi im Pelisztim” - „Niechaj ja zginę, ale razem z moimi wrogami”. Przed wami dwustu ludzi z karabinami, wy jesteście 8000 ludzi, którzy i tak nic nie mają do stracenia, a tamtym życie jest miłe. Wstańcie wszyscy razem, wydajcie jeden okrzyk, razem w jednej sekundzie, a już będziecie wolni.

Przeklęty jest naród żydowski, stary jest, już nie ma sił walczyć z przeciwnościami! [S 73-74]

Perechodnik utrwala funkcjonujący w antysemickich kręgach stereotyp Żyda-tchórza. Przekleństwo narodu żydowskiego polega na usilnym trwaniu jego członków w żydowskości. Nikt z Żydów nie buntuje się przeciwko nazistowskiemu dziełu zniszczenia, albowiem śmierć jest niejako wpisana w wielowiekową historię potomków Mojżesza. Żydzi przyzwyczaili się do cierpień w imię wyznawanej wiary,

11 Ławski, op. cit., s. 175.

12 M. Głowiń s ki, Nienawidzić siebie. „Nauka” 2004, nr 3, s. 10. 
teraz cierpią z zupełnie innego powodu. Zostali wykluczeni z nowoczesnego społeczeństwa na mocy założeń o czystości rasy. Na tej podstawie odmawia im się prawa do życia. Dawniej występowali przeciwko swoim ciemięzcom, dziś nie są zdolni do jakiejkolwiek formy oporu, a w dodatku karą za grzechy tłumaczą rozmiary żydowskiej gehenny. Perechodnik niemal na każdym kroku wytyka Żydom brak odwagi i pokorne przyjmowanie postawy biblijnego Hioba. Bardzo surowo ocenia żydowski naród i zasypuje go długą lista oskarżeń, choć sam czuje się na wskroś przesiąknięty żydowskim duchem. Według autora Spowiedzi miliony Żydów giną w równym stopniu na skutek niemieckiego sadyzmu oraz polskiej podłości, co i żydowskiego tchórzostwa ${ }^{13}$. Gdyby nie ortodoksyjne wychowanie Perechodnika i jego ścisły związek z żydowską społecznością, może zdobyłby się na akt ratowania córki i żony. Pewnie zginąłby w Treblince, lecz bez poczucia winy. Jednak pod wpływem strachu, tradycyjnych, żydowskich naleciałości podjął inną decyzję. Ona zaważyła na jego dalszym życiu, czyniąc ze świadka Zagłady zrozpaczonego sędziego ludzkości, który w ostrym i zaczepnym tonie oskarża: nazistowskich napastników, polskich donosicieli, żydowski naród, a przede wszystkim siebie - Calka Perechodnika, człowieka przeżywającego osobisty dramat przeklętej egzystencji.

\section{Perechodnik jako ofiara}

W literackim labiryncie oszczerstw, gniewu, pragnienia zemsty łatwo zagubić postać Perechodnika jako ofiary Zagłady. Należy pamiętać, iż służba w żydowskiej policji nie odbiera mu statusu pokrzywdzonego. Każdy Żyd był ofiarą nazistowskich działań, bez względu na zachowania i czyny, jakich się dopuszczał, aby zwiększyć swoją szansę na przetrwanie. Nawet Chaim Rumkowski - karykaturalny bohater opowiadania Adolfa Rudnickiego (Kupiec tódzki) i powieści Andrzeja Barta (Fabry$k a$ muchołapek) to człowiek głęboko dotknięty systemowym aparatem represji ${ }^{14}$. Perechodnik przyznaje się do winy. Nie szuka usprawiedliwień, nie tłumaczy się niezdolnością do podjęcia optymalnej decyzji. Jest morderca i nikt poza żoną nie może go rozgrzeszyć. Ale współczesny czytelnik powinien spojrzeć na sylwetkę Perechodnika także z perspektywy rzeczywistości, w której przyszło mu wieść tragiczny żywot. Rzeczywistości nieludzkiej. Rzeczywistości, w której prym wiodła tzw. moralność wyłączona. Barbara Engelking tłumaczy, że zarówno w getcie, jak i poza nim dochodzi do zburzenia dotychczasowego porządku moralnego. Liczy się jedynie

Calek Perechodnik w autorskiej dedykacji wyznacza trzy podmioty żydowskiego zagrożenia, oskarżając „S.N., P.P., T.Ż”, które to skróty rozszyfrowujemy jako „sadyzm niemiecki, podłość polską oraz tchórzostwo żydowskie”. Zob. S 7, przypis 1.

14 Obraz życia Rumkowskiego został dokładnie zrekonstruowany przez M. Polit w książce Mordechaj Chaim Rumkowski. Prawda i zmyślenie (Warszawa 2012). Badaczka rozbijając liczne stereotypy narosłe wokół postaci przełożonego Starszeństwa Żydów w Łodzi, znane m.in. z kart polskiej literatury, podkreśla, że Rumkowski był przede wszystkim ofiarą Zagłady, a jego postępowanie miało zapewnić gettu w Łodzi jak najdłuższe przetrwanie. J. Hensel lOfiary $i$ świadkowie. Wiersze czasu wojny jako źródło wiedzy o Zagładzie. W zb.: Literatura polska wobec Zagłady. Red. A. Brodzka-Wald, D. Krawczyńska, J. Leociak. Warszawa 2000, s. 51-52) uważa Kupca łódzkiego za klasyczne przedstawienie ofiary jako sprawcy Zagłady. 
chęć przeżycia za wszelką cenę ${ }^{15}$. Trudno oceniać wybór Perechodnika według kryteriów „normalnego” świata, tym bardziej że w praktyce nie miał on żadnego wyboru. Cóż to za wybór, jeśli za każdym kryje się czyjaś śmierć?

Przyjęta przez autora konwencja poetyki spowiedzi przerzuca rozmiary żydowskich krzywd na osoby jego bliskich. $Z$ dziejów Zagłady żydowskiego narodu wyłania się równie bolesna dla Perechodnika zagłada mikroświata, w którym się poruszał, skupionego wokół potwornych losów żony i córki pisarza, a może jeszcze szerzej: wokół jego ojca, matki, znajomych. W obliczu krystalicznych sylwetek pomordowanych nie wypada mówić Perechodnikowi o sobie jako o ofierze Zagłady. Klęska funkcjonariusza żydowskiej policji nie zostaje wypowiedziana wprost, lecz pośrednio, poprzez figurę milczenia. Tomasz Żukowski podkreśla, iż milczenie należy do najczęstszych sposobów budowania wypowiedzi w analizowanym pamiętniku. Według badacza stanowi ono część rytuału, „Oznacza podwójną zgodę: na to, co się dzieje, i na to, jak się o tym mówi. Potwierdza uczestnictwo w grze, której zasady narzuciła większość”16. Dla przeważającej części świadków Zagłady autor Spowiedzi jest zbrodniarzem, on sam przychyla się do brutalnego osądu otoczenia. Dziś musimy odnaleźć w historii Calka życiowy dramat. Dramat człowieka, który stracił kontakt $\mathrm{z}$ najbliższymi i pogrążył się $\mathrm{w}$ otchłaniach pustki.

Na zakończenie chciałbym zacytować obszerną notatkę Perechodnika opisującą powrót zrezygnowanego ojca i męża do wysiedlonego miasta.

Pamiętam, jak szliśmy: ja, Zygmunt Wolfowicz, jego brat Tadek oraz Rubin Grynkorn. Mieszkaliśmy na tej samej ulicy, jednocześnie straciliśmy rodziny i teraz wracamy do domów, instynktownie trzymając się jeden drugiego.

Czy może strach nas obleciał przed wymarłym gettem? Czy może boimy się samotności? Nie, my boimy się zostać sami przed tak wrogim i wszechwiedzącym sędzią, jakim jest własne sumienie. [...]

Milcząc zasiadamy do kolacji - tak, natura ma przecież swoje prawa. Smarujemy chleb grubo masłem, pijemy kakao, mocno słodzone.

Boże, czy to jest orgia? Nie, jest to ostatnia wieczerza skazańców. Takie kolacje będziemy odtąd zjadać codziennie, któraś z nich będzie tą ostatnią, ale jak wiedzieć która? Czy to już ta dzisiejsza, czy może jeszcze nie? [S 84-85]

Widok wyludnionego Otwocka można rozumieć jako pewien symbol przeżycia Zagłady. Perechodnik $z$ trudem wraca do rodzinnego mieszkania. Instynktownie szuka obecności drugiego człowieka, lecz odkrywa przerażająca prawdę. Żadnego z jego przyjaciół nie stać na odruch płaczu czy współczucia. Cierpienie nie łączy, lecz dzieli, potwierdzając jedynie nieuniknioność totalnej katastrofy. Tam, na kolejowym placu, została wytyczona cienka granica człowieczeństwa, po której przekroczeniu nie ma już powrotu do normalności. Perechodnik pragnałły zrzucić ciężar zbrodni na kogoś innego, przekazać straszliwą spuściznę Shoah komuś, kto zrozumiałby jego wyobcowanie, lecz obok brakuje człowieka gotowego na przyjęcie takiego wyzwania. I w tym tkwi największa tragedia ludzi skazanych na doświadczenie Zagłady.

B. Engelking, Zagłada i pamięć. Doświadczenie Holocaustu i jego konsekwencje opisane na podstawie relacji autobiograficznych. Warszawa 1994, s. 115.

16 T. Ż u k ow s ki, Savoir-vivre. Ironiczne strategie w „Spowiedzi” Calka Perechodnika. „Teksty Drugie" 2010, nr 6, s. 49. 


\section{Wyzwanie}

Perechodnik zginą, lecz pozostawił po sobie wyjątkowe dzieło - sumę łez, zwątpień rozczarowań, chwilowych wzlotów i bolesnych upadków. Budując pomnik ku czci ukochanej żony i córki zawarł w nim sporo informacji o własnym, wewnętrznie rozdartym ego. Obcowanie $z$ tekstem Spowiedzi to niewatpliwie wielkie wyzwanie dla dzisiejszego odbiorcy. Tym większe, gdy ma się do czynienia z pamiętnikiem pisanym przez autora współpracującego $\mathrm{z}$ nazistowskim oprawcą. Myślę jednak, że najważniejsze w lekturze Spowiedzi jest dostrzeżenie w niej skali cierpienia, jakiemu poddany był skazany na klęskę Żyd. Człowiek z krwi i kości, nie bojący się przyznać do błędów popełnionych w przeszłości. Wnikliwa lektura relacji Perechodnika pozwala wytyczyć jeszcze jedną perspektywę odczytywania literackich świadectw Holocaustu. Rzuca nowe światło na działalność Żydów-kolaborantów. Niektórzy z nich, w tym Perechodnik, do końca życia żałowali tego, że przyłączyli się do armii zbrodniarzy. Spowiedź to swego rodzaju balans między obowiązkiem moralnym względem rodziny a powinnościa wobec narodu ginącego $\mathrm{w}$ obozach Zagłady. Jest to dylemat etyczny ujawniający się w przekroju całej twórczości o Shoah. Perechodnik zrozumiał, że oba obowiązki są równie ważne, dlatego stworzył wspaniały „hymn” ku czci żony i córki, przedstawiając postacie najbliższych na tle tragicznych dziejów żydowskiego narodu.

Abstract

GRZEGORZ SIEROCKI Pomeranian University, Słupsk

EXECUTIONER, JUDGE AND VICTIM IN CALEL PERECHODNIK'S "SPOWIEDŹ" (“CONFESSION")

Calel Perechodnik's Spowiedź (Confession) should be placed among the most important evidence of the Holocaust. It is a unique work as it was produced by a man who collaborated with the Nazi oppressor. Jewish police uniform did not save the author of the memoirs from a personal tragedy. Finally, he himself had to lead his wife and daughter to the train of death heading for Treblinka, which greatly influenced on the subject and form of his account.

Perechodnik describes the reality of occupation from three different points of view: an executioner, a judge, and a victim. The first two may arise controversies among wider public as Confession is not only a literary examination of conscience, but also a penetrating act of indictment in which the author does not spare his native society. For that reason it is easy to lose the figure of Perechodnik as a victim of Shoah.

A careful reading of Confession offers one more perspective of understanding the literary evidence of the Holocaust since it sheds a new light on the activities of Jews-collaborators. Some of them till the end of their lives regretted that they joined the army of oppressors. Perechodnik's Confession is a certain balance between moral duty towards family and nation dying in concentration camps. It is a moral dilemma running through the entire creativity about the Shoah. 